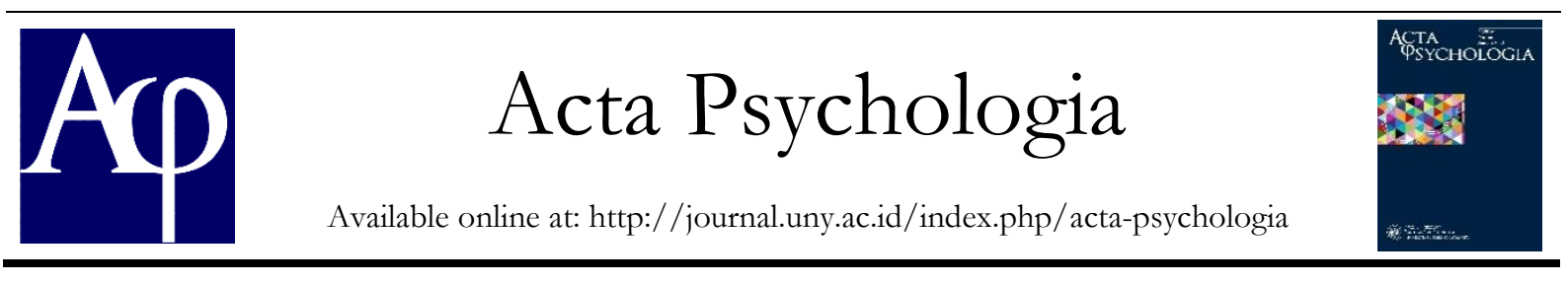

\title{
Relasi antara Orang tua dan Anak Ditinjau dari Sudut Pandang Remaja dengan Perilaku Delinkuen
}

\author{
Nourmarifa Sari \\ Jurusan Psikologi, Fakultas Ilmu Pendidikan, Universitas Negeri Yogyakarta; \\ Jl. Colombo No. 1 Sleman Yogyakarta, 55281 \\ nourmarifa.sari@gmail.com
}

\begin{abstract}
Abstrak
Penelitian ini bertujuan untuk mengetahui relasi antara orang tua dan anak menurut sudut pandang remaja yang memiliki perilaku delinkuen. Penelitian ini menggunakan metode kualitatif dengan pendekatan fenomenologis. Responden penelitian ini adalah 2 orang remaja laki-laki berusia 16-20 tahun yang memiliki skor skala delinkuensi $\geq 17$. Skala delinkuensi yang digunakan dalam penelitian yaitu Skala Delinkuensi Theunnisen yang telah dialih bahasa dan disesuaikan kembali dengan konteks di Indonesia. Hasil penelitian menunjukkan bahwa relasi menurut remaja yang memiliki perilaku delinkuen adalah adanya relasi yang bersifat positif dan negatif. Relasi yang bersifat positif di antaranya pengasuhan, transmisi nilai, kedekatan, perhatian, dan kebersamaan. Relasi yang bersifat negatif di antaranya adalah kurangnya dukungan, minimnya pemahaman, kesalahan komunikasi antara orang tua dan anak, juga adanya konflik yang tidak disertai dengan manajemen konflik yang baik.
\end{abstract}

Kata Kunci: relasi orang tua anak, remaja delinkuen, relasi, kualitatif

\begin{abstract}
This study aims to determine the relationship between parents and children from the perspective of adolescents with juvenile deliquency. This study used qualitative methods with a phenomenological approach. The research subjects were two boys aged 16-20 years who had a delinquency scale score $\geq 17$. In addition, the researcher uses the Theunnisen Delinquency Scale, as a deliquency scale, which has been translated and adjusted to the current conditions in Indonesia. As the result, it can be showed that relations according to adolescents with risky behavior were the existence of positive and negative relations. Positive relationships such as nurturing, transmitting values, closeness, attention, and togetherness. Negative relationships such as lack of support, lack of understanding, communication errors between parents and children, and conflicts that are not accompanied by good conflict management.
\end{abstract}

Keywords: parent and child relations, juvenile delinquency, relations, qualitative

\section{Pendahuluan}

Masa remaja merupakan masa transisi individu yang sebelumnya anak-anak menjadi orang dewasa. Seperti yang dikemukakan oleh Piaget (dalam Santrock, 2003) masa remaja adalah masa seorang anak berinteraksi dengan masyarakat lain di sekitarnya yang lebih dewasa daripada dirinya. Dalam masa ini, anak sudah tidak lagi merasa berada di tingkatan lebih bawah dari orang-orang yang lebih tua. Remaja sudah berpikir mereka berada dalam tingkatan yang sama dengan orang lain. Masa remaja sering juga menjadi masa yang membingungkan. Individu yang berada pada masa remaja, sudah tidak bisa disebut sebagai anak-anak, namun juga tidak dapat disebut sebagai orang dewasa. Individu yang berada pada masa ini dihadapkan pada pertanyaan siapa mereka, apa potensi mereka sebenarnya, dan ke arah mana mereka akan menuju dalam hidupnya. 
Erikson (dalam Santrock, 2003) menyatakan bahwa remaja memiliki tugas untuk menemukan identitas diri mereka yang paling sesuai dengan dirinya. Oleh karena itu, masa remaja juga disebut sebagai masa pencarian jati diri, yaitu anak mempersiapkan diri untuk masa dewasanya. Remaja secara bertahap akan menyadari bahwa mereka bertanggung jawab akan diri mereka dan kehidupan mereka sendiri. Remaja akan mencari seperti apakah kehidupannya nanti (Santrock, 2003). Individu yang dapat melewati masa pencarian identitas diri dengan baik adalah remaja yang mampu menemukan identitas diri mereka dan mempersiapkan diri dengan baik untuk masa dewasanya.

Banyak remaja yang dapat melewati masa pencarian identitas diri dengan baik. Salah satu contohnya adalah yang diraih oleh Rebecca Alexandria yang memenangkan Youth America Grand Prix di New York, Amerika Serikat (Anonim, 2018). Rebecca menemukan bahwa dirinya kelak akan menjadi penari ballet profesional. Prestasi lain ditorehkan oleh 4 siswa SMA yang mewakili Indonesia dalam ajang Olimpiade Penelitian Tingkat Internasional Intel-ISEF di California, Amerika Serikat (Widhi K, 2017). Keempat siswa SMA ini mendapatkan penghargaan khusus dari berbagai macam lembaga di Amerika atas penelitian yang telah mereka lakukan pada ajang bergengsi tersebut. Contoh- contoh di atas menunjukkan bahwa remaja dapat menemukan identitas diri mereka melalui kegiatan- kegiatan yang positif.

Sebagian remaja dapat melewati masa pencarian jati diri dengan baik, namun ada pula remaja yang kurang dapat melewati masa pencarian jati diri. Salah satu bentuk dari kegagalan melewati masa pencarian jati diri adalah kenakalan remaja atau delinkuensi. Delinkuensi adalah suatu perilaku yang dilakukan oleh remaja yang menyalahi aturan sosial di sebuah lingkungan masyarakat tertentu (KBBI,
2016). Erikson (dalam Santrock, 2003) menyatakan bahwa delinkuensi ditandai dengan adanya kegagalan yang dilakukan oleh remaja dalam mencapai sebuah keadaan yang melibatkan berbagai macam aspek- aspek yang ada dalam pembentukan identitas diri. Menurut Erikson (dalam Santrock, 2003) juga berpendapat bahwa remaja yang cenderung melewati masa balita dan kanak-kanak dengan suasana atau keadaan yang membatasi mereka, akan cenderung kurang memiliki kemampuan untuk memenuhi tuntutan yang diberikan oleh lingkungannya kepadanya, akan cenderung mengembangkan sisi diri yang negatif atau sisi diri yang kurang baik.

Sutrisno (2016) dalam berita yang disampaikan melalui laman republika.co.id mengemukakan bahwa anak di bawah umur dan remaja mendominasi jumlah pelaku begal di Makassar. Data warga binaan di lembaga pemasyarakatan (LAPAS) kelas IIA Makassar yang berusia di bawah 18 tahun berjumlah 96 orang dengan latar belakang kasus yang bermacam-macam mulai dari pencurian, pemerkosaan, hingga pembunuhan (Syam, 2017). Hal ini menunjukkan bahwa remaja yang melakukan tindak kejahatan di Makassar jumlahnya mendominasi.

Berdasarkan data milik Kementrian Kesehatan RI pada tahun 2016 (Kementerian Kesehatan RI, 2016) menunjukkan bahwa jumlah persentase remaja pada usia 16-19 tahun yang merokok meningkat tiga kali lipat dari 7,1\% menjadi 20,5\% sejak tahun 1995 hingga tahun 2014. Data perokok pemula pada usia 10-14 tahun meningkat lebih dari 100\% dalam rentang waktu antara 1995 hingga 2013, yakni dari 8,9\% menjadi 18\% (Andayani, 2017). Pada tahun 2012, angka kehamilan remaja berusia 15-19 tahun mencapai 48 kasus dari 1.000 kehamilan (Survei Demografi dan Kesehatan Indonesia, 2013).

Berbagai macam peristiwa yang berkaitan dengan delinkuensi dapat kita 
temukan dengan mudah di masyarakat. Sebagai contoh adanya kasus pencabulan yang dilakukan oleh siswa SMP di Ambon (Hutapea, 2018). Siswa kelas 3 SMP tersebut membolos sekolah dan menemui korban yang notabene merupakan pacarnya, kemudian pelaku merayu korban hingga terjadilah tindakan pencabulan tersebut. Contoh lain yang sedang hangathangatnya dibicarakan di masyarakat dewasa ini ialah ditemukannya mayat pengemudi taksi online di sebuah perumahan di Semarang. Berdasarkan hasil penelusuran yang dilakukan oleh pihak kepolisian, didapatkan berbagai macam bukti yang mengarah pada 2 orang siswa sebuah SMK Negeri di Semarang. Kedua siswa sekolah ini diketahui menipu supir taksi online hingga akhirnya supir taksi tersebut dibunuh dan tersangka membawa lari mobil serta seluruh barang berharga milik korban (Assifa, 2018). Pada akhirnya polisi menangkap keduanya dan menjadikannya tersangka atas kasus pembunuhan tersebut.

Salah satu faktor yang memengaruhi terjadinya delinkuensi adalah ketiadaan penerapan pemberian dukungan keluarga dan praktek manajemen oleh orang tua (Santrock, 2003). Orang tua memegang peranan penting dalam membentuk kepribadian dan jati diri remaja. Relasi antara orang tua dan anak yang telah dibina sejak lahir dengan baik akan menumbuhkan keterikatan (attachment) atau ikatan relasi satu sama lain (Widiastuti \& Widjaja, 2004). Dirgagunarsa \& Sutantoputri (2004) mengemukakan bahwa relasi atau hubungan orang tua dengan anak pada keluarga normal memperlihatkan adanya afeksi yang hangat antara orang tua terhadap anak, serta anak terhadap orang tua.

Kepribadian anak dapat dibentuk melalui pola pengasuhan yang diberikan oleh orang tua. Oleh karena itu, hubungan antara orang tua dan anak sudah pasti merupakan suatu hubungan yang intim karena tidak akan terputus hingga kapanpun. Pola asuh orang tua serta berbagai macam respon orang tua kepada anak akan membentuk suatu ikatan antara anak dan orang tua sebagai sosok pengasuh. Berbagai macam perilaku orang tua kepada anak akan diterima, diresapi dan dipelajari oleh anak hingga sepanjang hidupnya. Penelitian yang dilakukan oleh Muqorrobin (2016) menjelaskan bahwa pola asuh orang tua memiliki korelasi yang signifikan terhadap kenakalan remaja. Herdiana (2016) menyatakan bahwa semakin otoriter pola asuh yang dilakukan oleh orang tua, maka tingkat kenakalan remaja akan semakin tinggi pula. Penelitian yang dilakukan oleh Garvin (2017) menunjukkan bahwa semakin orang tua menerapkan pola asuh authoritative, maka kecenderungan delinkuen pada remaja akan semakin rendah. Hasil penelitian yang dilakukan oleh Arif (2016) menunjukkan bahwa ada korelasi positif antara pola asuh permisif dengan kenakalan remaja.

Berdasarkan penelitian pendahuluan yang dilakukan oleh peneliti, didapatkan informasi tiga dari lima anak mengemukakan bahwa orang tua mereka kurang dapat memahami dan mengerti keinginan mereka. Orang tua mereka cenderung mengambil keputusan (dalam hal yang berkaitan dengan anak) tanpa mempertimbangkan keinginan dan kemauan anak. Anak- anak berkata bahwa apabila hal tersebut memang sangat perlu untuk dilakukan, sebaiknya orang tua memberikan alasan yang logis saat menjelaskan kepada mereka. Hal ini menunjukkan bahwa ada kesenjangan antara harapan dan kenyataan pada remaja tentang relasi mereka dengan orang tua. Oleh karena itu, permasalahan ini menjadi menarik untuk diteliti lebih dalam tentang relasi antara orang tua dan anak. Bagaimana remaja yang memiliki perilaku delinkuen melihat relasi antara orang tua dan anak?. 


\section{Metode Penelitian}

\section{Jenis penelitian}

Penelitian ini menggunakan pendekatan kualitatif dengan jenis fenomenologi.

\section{Waktu dan tempat penelitian}

Penelitian ini dilakukan pada bulan Januari sampai bulan Februari 2019. Penelitian dilaksanakan di Kota Semarang.

\section{Subjek penelitian}

Penentuan responden penelitian ini menggunakan metode purposive sampling, dengan kriteria responden sebagai berikut: (1) Remaja berusia 16 hingga 20 tahun; (2) Berada pada bangku Sekolah Menengah Atas/Sederajat; (3) Memiliki skor skala delinkuensi $\geq 17$ sehingga dapat dikatakan bahwa remaja tersebut merupakan remaja yang memiliki delinkuensi; (4) Tinggal di kota Semarang; dan (5) Bersedia menjadi responden penelitian.

\section{Prosedur}

Penelitian ini terdiri dari empat tahap. Tahap pertama yaitu peneliti melakukan screening kepada remaja usia 16 hingga 20 tahun yang berada pada bangku SMA/Sederajat. Tahap kedua yaitu peneliti memperkenalkan diri dan memberi informasi terkait tujuan penelitian kepada kedua responden penelitian. Tahap ketiga adalah peneliti melakukan wawancara mendalam kepada responden penelitian dan significant others. Wawancara dilaksanakan dengan menggunakan pedoman wawancara yang telah dipersiapkan. Tahap keempat yaitu peneliti melakukan probing, pengolahan data dan triangulasi data pada responden penelitian.

\section{Teknik pengumpulan data dan instrumen}

Data penelitian didapatkan langsung dari responden penelitian melalui wawancara mendalam kepada remaja serta ayah kandung dari 2 keluarga yang berbeda di Semarang. Instrumen yang digunakan dalam penelitian ini adalah peneliti, skala delinkuensi, dan pedoman wawancara. Masing-masing responden penelitian diwawancara kurang lebih tiga kali untuk mendapatkan informasi yang selengkaplengkapnya. Skala delinkuensi yang digunakan dalam penelitian disusun dengan menggunakan konsep dasar dari pengertian delinkuensi (seluruh perbuatan yang dilakukan oleh remaja, di mana perbuatan tersebut tidak sesuai dengan nilai dan norma yang dapat menimbulkan kecemasan serta ketidaknyamanan sosial dalam masyarakat serta dapat dikategorikan dalam tindakan kriminal.

Pedoman wawancara dibuat dengan menggunakan konsep relasi yang dikemukakan oleh Fiske (1992). Namun dalam penelitian ini hanya dua dari empat bentuk relasi yang digunakan. Pengambilan keputusan ini dilakukan dengan mempertimbangkan kemungkinan bentuk relasi yang muncul dalam relasi antara orang tua dan anak. Bentuk relasi tersebut adalah Authority Ranking dan Equality Matching.

Pedoman wawancara untuk orang tua dan anak secara mendetail bertujuan untuk menanyakan makna orang tua dan anak, kedekatan antara anak dengan orang tua, serta untuk mengetahui perasaan anak dan orang tua kepada satu sama lain. Peneliti juga menggali informasi tentang bagaimana pengasuhan orang tua, apa saja nilai- nilai yang diajarkan orang tua kepada anak serta bagaimana pengaruhnya kepada anak. Sebagai informasi tambahan, peneliti menggali tentang bentuk-bentuk perhatian dan kebersamaan orang tua dan anak demi menambah data penelitian.

Upaya lain yang dilakukan peneliti untuk menggali data atau informasi demi kekayaan data diantaranya adalah dengan membandingkan harapan serta realita hubungan antara anak dengan orang tua. Peneliti juga menanyakan tentang harapanharapan anak kepada orang tua serta harapan orang tua kepada anak untuk 
menambah informasi bahwa ada kesenjangan antara harapan dan realita dalam hubungan orang tua dan anak. Peneliti berupaya untuk menanyakan pandangan anak terhadap diri sendiri sebagai informasi tambahan guna menarik dinamika psikologis responden penelitian.

\section{Teknik Analisis data}

Analisis data pada penelitian ini menggunakan analisis data kualitatif berdasarkan Miles dan Huberman (1992) yang terdiri dari tiga langkah pengolahan data, yaitu reduksi data (data reduction), penyajian data (data display), dan penarikan kesimpulan (conclusion drawing and verification). Data yang diperoleh dari hasil wawancara disederhanakan, selanjutnya disajikan dengan bentuk naratif. Peneliti menyusun tabel hasil wawancara untuk memudahkan dalam membaca.

\section{Hasil Penelitian dan Pembahasan}

\section{Relasi orang tua dan anak}

Peneliti memilih 2 orang remaja laki-laki yang memiliki skor tertinggi berdasarkan hasil skala delinkuensi yang digunakan sebagai alat screening. Berdasarkan hasil analisis yang telah dilakukan, didapatkan hasil yaitu relasi antara orang tua dan anak menurut remaja yang memiliki perilaku delinkuen, bentuk-bentuk relasi tersebut dapat dilihat pada Tabel 1.

Tabel 1. Rangkuman hasil penelitian

\begin{tabular}{ll}
\hline Relasi positif & Relasi negatif \\
\hline - Pengasuhan & - Kurangnya dukungan \\
- Tranmisi nilai & - Kurangnya \\
- Kedekatan & pemahaman \\
- Perhatian & - Kesalahan \\
- Kebersamaan & komunikasi \\
& - Konflik \\
\hline
\end{tabular}

Berdasarkan Tabel 1, relasi antara orang tua dan anak menurut remaja yang memiliki perilaku delinkuen terbagi menjadi 2 bentuk, yaitu relasi yang bersifat positif, serta relasi yang bersifat negatif. Relasi yang bersifat positif terdiri dari pengasuhan, transmisi nilai, kedekatan, perhatian, serta kebersamaan. Sedangkan relasi yang bersifat negatif terdiri dari kurangnya dukungan, kurangnya pemahaman, adanya kesalahan komunikasi, serta adanya konflik dalam hubungan orang tua dan anak.

Salah satu relasi antara anak dengan orang tua ialah pengasuhan. Definisi pengasuhan yang disampaikan oleh responden penelitian selaras dengan definisi pengasuhan menurut Brooks (2011), yaitu orang tua sebagai individu yang mengasuh, melindungi dan membimbing anak dari bayi hingga dewasa. Pengasuhan dikatakan juga sebagai sebuah proses yang merujuk pada serangkaian aksi dan interaksi yang dilakukan oleh orang tua untuk mendukung perkembangan anak.

Pembelajaran yang didapatkan oleh kedua responden dari orang tuanya membuktikan bahwa dalam hubungan orang tua dan anak terdapat sebuah pembelajaran yang diberikan dari generasi ke generasi. Hal ini sesuai dengan pendapat yang dikemukakan oleh Lestari (2014) bahwa dalam transmisi budaya, suatu kelompok budaya mengabadikan ciri-ciri perilakunya kepada generasi selanjutnya lewat metode mengajar (teaching) dan belajar (learning).

Jenis perhatian yang muncul dalam hubungan antara responden dengan kedua orang tuanya berupa pertanyaan-pertanyaan yang bertujuan untuk mengingatkan kegiatan- kegiatan kecil yang setiap hari dilakukan. Hal ini sesuai dengan pendapat Kartini Kartono (dalam Suparyoto, 2011) yang menyatakan bahwa perhatian adalah pemusatan tenaga psikis tertuju pada kepada suatu objek. Dalam hal ini bermakna bahwa orang tua memusatkan tenaga psikisnya kepada anak yakni dengan cara menanyakan kegiatan anak serta memenuhi segala kebutuhan anak. 
Kementrian Pendidikan dan Kebudayaan Republik Indonesia (2017) mengemukakan bahwa yang menentukan kualitas kebersamaan adalah adanya interaksi dua arah antara orang tua dan anak. Apabila kebersamaan antara orang tua dan anak memiliki kualitas yang baik, dapat menimbulkan ikatan emosi antara orang tua dan anak yang lebih kuat, anak-anak dapat terbuka kepada orang tua, dapat melatih anak untuk bergaul, serta anak menjadi lebih bahagia.

Kesalahan komunikasi yang muncul pada relasi kedua responden berbeda. Salah seorang responden memiliki komunikasi yang kurang baik dengan ayah dan responden yang lain dengan ibu. Respon yang diberikan kedua responden cenderung sama, yaitu tidak mengkomunikasikan sudut pandangnya tersebut kepada orang tuanya. Grotevant dan Cooper (1985) menyatakan bahwa anak memiliki kesadaran akan sudut pandangnya sendiri dan memiliki rasa tanggung jawab untuk mengkomunikasikan secara jelas dengan orang lain. Hasil penelitian ini menunjukkan bahwa responden kurang memiliki kesadaran terhadap diri sendiri akan penegasan sudut pandangnya kepada orang lain dengan cara mengkomunikasikannya secara jelas.

Konflik antara kedua responden dengan orang tuanya secara umum berbentuk verbal dan fisik. Penyebab terjadinya konflik dalam hubungan ini adalah karena responden melanggar larangan yang telah diberikan oleh orang tuanya. Hal ini sesuai dengan pendapat yang dikemukakan oleh Thomas (dalam Laela, 2015) yang menyatakan bahwa konflik bermula pada saat salah satu pihak menganggap pihak yang lain berupaya untuk menggagalkan kepentingannya. Pada saat konflik berlangsung, anak cenderung merasa sakit hati dan marah kepada orang tua, hal ini sesuai dengan yang dikemukakan oleh Laela (2015) bahwa perasaan positif yang dibangun secara mendalam dapat berubah menjadi perasaan negatif yang mendalam juga karena adanya konflik.

Dalam penelitian ini, muncul tuntutan untuk hidup sesuai dengan keinginan orang tua, hidup dengan meniru orang tua dan menuruti perkataan orang tua yang menunjukkan bahwa dalam relasi ini terdapat peraturan atau perintah tertentu yang diberikan oleh orang tua kepada anaknya. Seperti yang diungkapkan oleh Fiske (1992) bahwa dalam sebuah relasi terdapat kekuasaan yang didasarkan pada sebuah rantai tertentu yang ditandai dengan adanya tindakan untuk membuat peraturan atau memerintah orang lain (Authority Ranking). Dalam relasi ini, orang tua menunjukkan kekuasaan atau otoritas yang dimiliki kepada anak yang posisinya berada di bawah orang tua.

Adanya upaya untuk mewujudkan harapan antara orang tua kepada anak, serta anak kepada orang tua menunjukkan bahwa orang tua dan anak saling bergantung satu sama lain untuk bahu-membahu mewujudkan harapan mereka. Sesuai dengan yang diungkapkan oleh Fiske (1992) bahwa dalam sebuah relasi terdapat pertukaran bolak-balik antar individu untuk mendapatkan keseimbangan dalam hubungan tersebut. Dalam relasi ini, orang tua dan anak saling menaruh harapan satu sama lain yang disertai dengan berbagai upaya untuk mewujudkan harapan tersebut (Equality Matching). Orang tua dan anak saling bergantung satu sama lain sebagai upaya mewujudkan harapan mereka di mana apabila harapan tersebut terwujud, mereka saling menguntungkan satu sama lain.

\section{Dinamika relasi}

Kurangnya dukungan serta adanya kesalahan komunikasi antara orang tau dengan anak menimbulkan konflik dalam 
relasi antara orang tua dan anak menimbulkan konflik dalam relasi tersebut. Minimnya upaya manajemen konflik dalam relasi ini, disertai oleh adanya pengaruh dari faktor internal (pengembangan identitas diri yang negatif serta kontrol diri yang rendah) yang menyebabkan anak menjadi memiliki kecenderungan untuk memiliki perilaku delinkuen. Santrock (2003) menyatakan bahwa faktor yang menyebabkan delinkuensi pada remaja ada empat faktor, yaitu: pembentukan identitas diri yang negatif pada remaja, kegagalan remaja dalam mengembangkan kontrol diri, terganggu atau tidak adanya dukungan keluarga serta praktek manajemen orang tua yang tidak konsisten, dan adanya pengaruh dari lingkungan sekitar dan masyarakat.

\section{Simpulan dan Saran}

\section{Simpulan}

Berdasarkan penelitian yang sudah dilakukan, dapat diambil kesimpulan bahwa relasi menurut remaja yang memiliki perilaku delinkuensi adalah adanya beberapa hal yang bersifat positif dan negatif. Relasi yang bersifat positif di antaranya yaitu: pengasuhan, transmisi nilai, kedekatan, perhatian, dan kebersamaan. Sedangkan relasi yang bersifat negatif di antaranya adalah kurangnya dukungan, kurangnya pemahaman, kesalahan komunikasi antara orang tua dan anak, dan adanya konflik yang tidak disertai dengan manajemen konflik yang baik. Kurangnya dukungan, kurangnya pemahaman dan adanya kesalahan komunikasi antara orang tua dan anak menimbulkan konflik dalam relasi tersebut. Tidak adanya manajemen konflik yang baik dari orang tua maupun anak terhadap konflik yang muncul, serta adanya pengaruh dari faktor internal (pengembangan identitas diri negatif dan kontrol diri yang rendah) menyebabkan tumbuhnya kecenderungan untuk berdelinkuensi pada anak.
Saran

Berdasarkan kesimpulan yang telah disebutkan sebelumnya, peneliti akan memberikan saran kepada beberapa pihak di antaranya adalah:

1. Bagi anak

Anak diharapkan dapat belajar mengkomunikasikan apa yang dirasakan kepada orang tua dengan menggunakan bahasa dan intonasi suara yang baik disertai dengan melihat kondisi orang tua apakah dirasa dalam kondisi yang baik ataukah tidak untuk menerima pendapat anak

\section{Bagi orang tua}

Konflik orang tua tua dan anak dapat di atasi serta dicegah dengan adanya komunikasi yang baik antara orang tua dengan anak. Orang tua dapat memperbaiki komunikasi yang sebelumnya kurang baik dengan cara mendengarkan pendapat anak serta mengikutsertakan anak dalam pengambilan keputusan bersama. Sebaiknya orang tua tidak melarang anak untuk mengemukakan pendapatnya dan lebih terbuka terhadap anak.

3. Bagi peneliti selanjutnya

Jika peneliti ingin melakukan penelitian yang sama, disarankan untuk dapat menambah jumlah responden penelitian, memperluas cakupan usia responden serta menambah variasi jenis kelamin responden penelitian. Dalam pengambilan data, peneliti selanjutna diharapkan dapat melakukan wawancara kepada ibu responden juga dan disertai dengan observasi kepada responden penelitian agar mendapatkan hasil yang lebih detail dan maksimal. 


\section{Daftar Pustaka}

Andayani, F.T. (2017). Peran relasi orang tua- anak dan tekanan teman sebaya terhadap kecenderungan perilaku pengambilan risiko pada remaja di Yogyakarta. Tesis, tidak diterbitkan. Universitas Gadjah Mada, Yogyakarta.

Arif, M. I. S. (2016). Hubungan pola asuh permisif dengan kenakalan remaja. E-Journal UNESA, 0- 216.

Assifa, F. (2018, Januari 24). Kepala smk kaget dua siswanya bunuh sopir taksi online. Kompas. Diakses dari regional.kompas.com.

Badan Pengembangan dan Pembinaan Bahasa. (2016). Kamus besar bahasa Indonesia $V$. Jakarta: Kementerian Pendidikan dan Kebudayaan Republik Indonesia.

Brooks, J. (2011). The process of parenting, proses pengasuban edisi kedelapan. (Alih Bahasa: Rahmat Fajar). Yogyakarta: Pustaka Pelajar.

Anonim. (2018, Oktober 22). Balerina Remaja Berprestasi. Media Indonesia. Diakses dari mediaindonesia.com.

Dirgagunarsa, Y.S., \& Sutantoputri, N.W. (2004). Hubungan orang tua dan remaja. Jakarta: BPK Gunung Mulia.

Fiske, A.P. (1992). The four elementary forms of sociality: framework for a unified theory of social relations. Psychologichal Review, 99(4), 689-723.

Garvin, G. (2017). Pola asuh orangtua dan kecenderungan delinkuensi pada remaja. Jurnal Psikologi Psibernetika, 10(1), 30-39.

Grotevant, H.D., \& Catherine R. C. (1985). Patterns of interaction in family relationship and the development of identity exploration in adolescence. Child Development, 56(2), 415-428.
Herdiana, N. (2016). Hubungan antara pola asuh otoriter dengan kenakalan remaja di sman 1 kutupanjang. Skripsi, tidak diterbitkan, Universitas Medan Area, Medan.

Hutapea, E. (2018, 26 Februari). Cabuli pacarnya saat bolos sekolah, siswa smp ini berurusan dengan polisi. Kompas. Diakses dari regional.kompas.com.

K., Nograhany W. (2017, 24 Mei). Inspiratif? 4 siswa sma ri raih penghargaan riset dunia. Detik. Diakses dari detik.com.

Kementerian Kesehatan RI. (2016). Profil kesehatan indonesia tahun 2015. Jakarta: Kementerian Kesehatan RI.

Kementerian Pendidikan dan Kebudayaan RI. (2017). Waktu berkualitas bersama anak. Jakarta: Kementerian Kesehatan RI.

Laela, F. N. (2015). Bimbingan konseling keluarga dan remaja. Surabaya: UIN Sunan Ampel Press.

Lestari, S. (2014). Psikologi keluarga penanaman nilai dan penanganan konflik dalam keluarga. Jakarta: Kencana Prenada Media Group.

Muqorrobin, A.L.Z. (2016). Pengaruh pola asuh orang tua terhadap kenakalan remaja siswa kelas X dan XI SMKN 2 Malang. Skripsi, tidak diterbitkan. Universitas Islam Negeri Maulana Malik Ibrahim, Malang.

Santrock, J.W. (2003). Adolescence: perkembangan remaja. Jakarta: Erlangga.

Suparyoto, S. (2011). Hubungan perhatian orang tua dengan prestasi belajar siswa kelas V SD Negeri Keputran A Yogyakarta. Skripsi, tidak diterbitkan. Universitas Negeri Yogyakarta, Yogyakarta.

Survei Demografi dan Kesehatan Indonesia. (2013). Kesehatan 
reproduksi remaja. Jakarta: Badan Pusat Statistik.

Sutrisno, D. (2016, 4 Januari). Anak di bawah umur dominasi pelaku begal di makassar. Republika. Diakses dari republika.co.id.

Syam, H. (2017). Dinamika keterlibatan remaja menjadi pelaku begal. Tesis, tidak diterbitkan. Universitas Gadjah Mada, Yogyakarta.

Widiastuti, N. \& Widjaja, T. (2004). Hubungan antara kualitas relasi ayah dengan harga diri remaja putra. Jurnal Psikologi, 2(1), 22-43. 